\title{
THE TRANSFERABILITY OF FRACTURE-MECHANICS PARAMETERS TO FRACTURE PERFORMANCE EVALUATION OF WELDS WITH MISMATCHING
}

\author{
PRENOSLJIVOST PARAMETROV MEHANIKE LOMA ZA \\ OCENITEV LOMNE SPOSOBNOSTI TRDNOSTNO RAZLIČNIH \\ ZVAROV
}

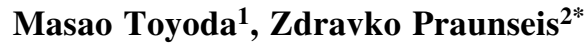 \\ 1Osaka University, Faculty of Engineering, 2-1 Yamada-Oka, Suita, Osaka 565-087, Japan \\ 2JSPS Visiting Scientist at Osaka University, Faculty of Engineering, 2-1 Yamada-Oka, Suita, Osaka 565-087, Japan \\ *University of Maribor, Faculty of Mechanical Engineering, Smetanova 17, 2000 Maribor, Slovenia \\ Prejem rokopisa - received: 2000-10-10; sprejem za objavo - accepted for publication: 2000-12-10
}

\begin{abstract}
The differences in the mechanical properties between different weld-metal regions obviously affect the strain distribution around the crack tip during a fracture test and hence influence the fracture-toughness value. The variation in plastic constraint during fracture-mechanics testing has an additional effect on the ductile and brittle fracture initiation behavior of any weld joint. This paper deals with the transferability of fracture-toughness results to the fracture-performance evaluation of the strength of mismatch welded joints based on the two-parameter criterion and the local approach. It was found that the numerical simulations based on the transferable fracture concept are effective in practise.

Key words: welded joints, strength mismatching, plastic constraint, transferability concept

Razlike mehanskih lastnostih med posameznimi področji vara vplivajo na porazdelitev plastičnih deformacij na konici razpoke že med izvajanjem lomno mehanskega preizkušanja in s tem tudi na velikost lomne žilavosti. Spremembe omejevanja plastične deformacije med lomno mehanskim preizkušanjem še dodatno vplivajo na iniciacijo žilavega in krhkega loma v zvarnem spoju.

V članku je opisana prenosljivost rezultatov lomne žilavosti za ocenitev lomnega vedenja trdnostno različnih zvarnih spojev na osnovi dvoparametrskega merila in lokalnega načina. Potrjena je praktična uporaba numeričnih simulacij, ki temeljijo na uporabi prenosljivega lomnega koncepta.

Ključne besede: zvarni spoji, trdnostna neenakost, omejevanje plastične deformacije, koncept prenosljivosti
\end{abstract}

\section{INTRODUCTION}

The fracture-mechanics approach has been the dominat method used to evaluate the fracture performance of welded steel structures. Nevertheless, some researchers have expressed doubts on the transferability of the fracture-controlling parameter in common fracture mechanics despite the fact that welding mechanics based on fracture mechanics has played an important role in avoiding the unstable fracture of welded structures. This inconsistency is brought about as a result of the difference in the plastic constraint, in the vicinity of a pre-existing crack, between the fracture-toughnesstesting specimen and practical structures. As a consequence, a new procedure should be introduced for engineering fracture assessment. Moreover, in the fracture-performance assessment of welded structures the change in the plastic constraint has to be considered because the defect is likely to be along the fusion line and in the weld metal where the mismatching of metallurgical and mechanical properties inevitably exists.

In the assessment of welded structures the consideration of both strength mismatching and transferability cannot be avoided. In this paper we first review the effects of the mismatch observed in welded joints on strength and fracture, and show that the plastic constraint due to strength mismatching plays an important role in fracture-initiation behavior for both ductile and brittle cracks. Secondly, we review the transferable concepts while accounting for the difference in plastic constraint and consider both geometrical discontinuity and mechanical mismatching. Finally, the applicability of transferable concepts for brittle and ductile fracture initiation has been proven with experimental work.

\section{MISMATCHING IN WELDED JOINTS AND ITS EFFECT ON FRACTURE}

Welded joints inevitably have some special characteristics which make them different from the base metal. Figure 1 shows typical characteristics of steel weldments, in particular the characteristics related to mismatching. The most important characteristics in terms of the fracture behavior of welded joints can be summarized as follows ${ }^{1}$ :

1. Change due to local plastic deformation resulting from the weld's thermal history:

Residual weld stresses and weld deformations. 


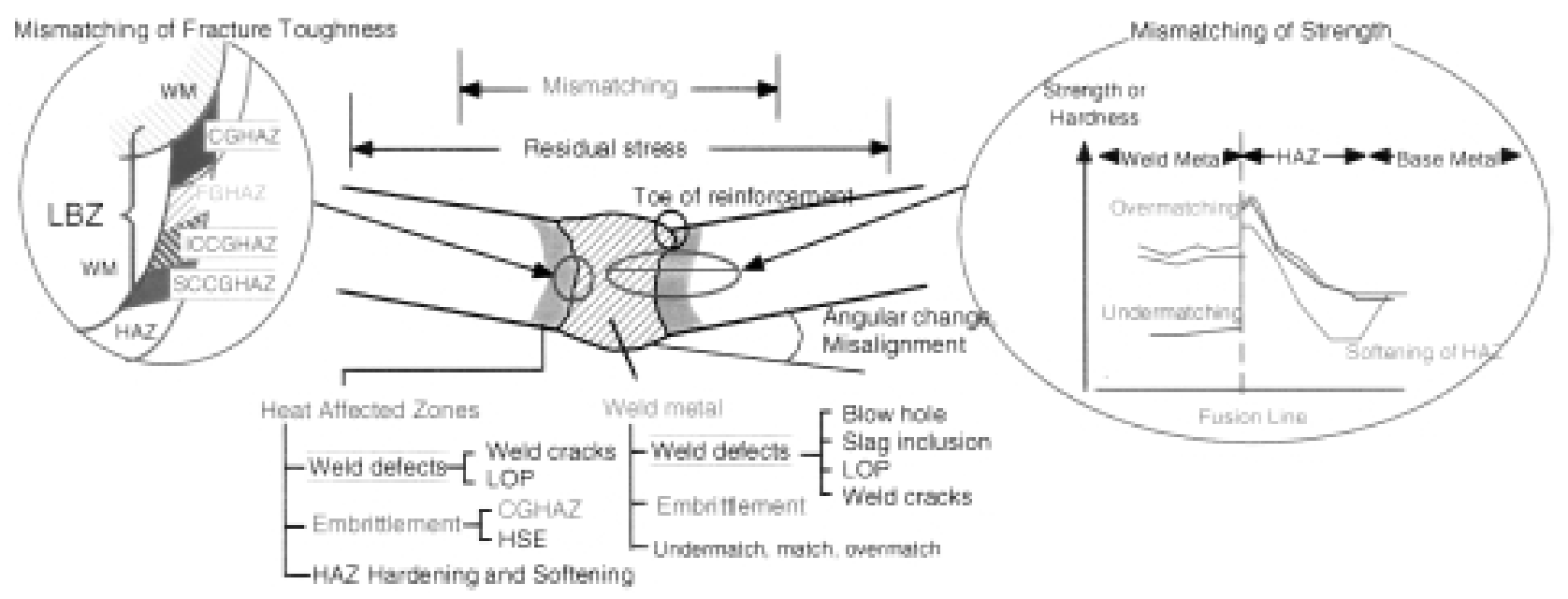

Figure 1: Typical characteristics of welded steel joint

Slika 1: Glavne značilnosti zvarnih spojev

2. Metallurgical and mechanical changes resulting from the weld's thermal history:

Mismatching in strength and ductility

Mismatching in fracture resistance (fracture toughness)

3. Existence of a geometrical discontinuity:

Weld defects and stress concentrators, etc.

In these characteristics, the mismatching in welded joints sometimes plays an important role in the fractureinitiation behavior in terms of both fracture toughness and the deformation behavior of cracked joints. Typical sizes of brittle zones in common multi-layered welded joints are in the sub-millimeter range. This is the reason for the local brittle zone (LBZ) problem.

In the common-fracture mechanics concept, the fracture parameters including the applied stress and geometrical conditions such as crack size have been adopted for evaluating the fracture behavior of a cracked body. The critical value of the parameters is called the fracture toughness. The fracture toughness obtained by using a certain method is called a material constant. The upper part of Figure 2 shows the conventional fracturemechanics concept for evaluating whether the critical condition for brittle fracture occurs or not. In other words, the possibility of the occurrence of a fracture can be evaluated by comparing the magnitude of both values.

The mismatching in both strength and fracture toughness observed in welded joints affects both fracture parameters and critical fracture values, as shown in Figure 2. The strength mismatching mainly influences the fracture parameters that control the stress-strain behavior. Consequently, it is most important to find an appropriate parameter that controls stresses and strain in the vicinity of a crack tip regardless of the degree of strength mismatching and the geometry of the specimens. If the common parameters such as the $\mathrm{J}$ integral and the crack-tip opening displacement (CTOD) - $\delta$, are adopted, the critical toughness values such as $\mathrm{J}_{\mathrm{c}}$ and $\delta_{c}$ are apparently influenced by the strength mismatching through the change of the plastic constraint. The existence of the mismatching in strength is the cause of the transferability problem with fracture toughness data obtained by conventional toughness tests in the evaluation of the fracture performance of practical structures. On the other hand, the problem related to mismatching in fracture toughness consists mainly in the question of how to evaluate the fracture toughness of welded joints with LBZs.

In ductile crack initiation, the plastic constraint should influence the critical situation of ductile crack initiation due to the existence of strength mismatching. It is important to find appropriate transferable fracture criteria by considering the change in the plastic constraint due to the existence of typical characteristics for welded joints.

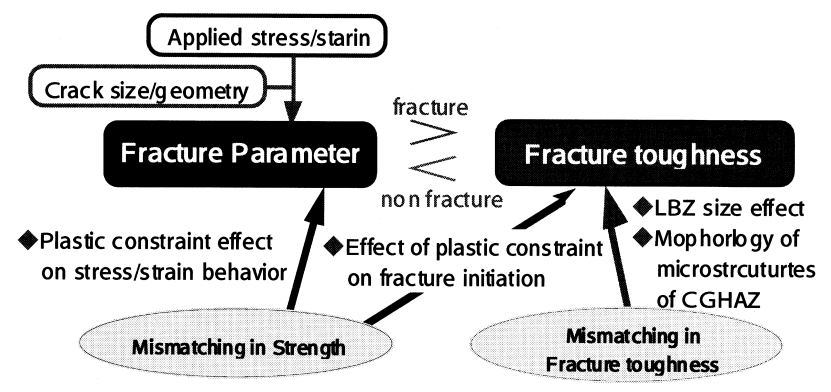

Figure 2: Effect of mismatching on fracture-mechanics approach Slika 2: Vpliv trdnostne neenakosti na lomno mehanski način 


\section{SUMMARY OF RESEARCH ON STRENGTH MISMATCHING}

The large number of studies of the effect of mismatching on the deformation behavior and joint performance of welded joints is summarized in Figure 3.

Studies of the strength of mismatched weld joints, in particular welded joints with a lower strength zone, have been conducted in Japan since the late 1960s. A lot of research at that time ${ }^{2-5}$ focused on the practical application of Q-T-type high-strength steels. The practical use of under-matched weld joints had also become popular for the welding of bridges and penstocks ${ }^{6}$. The authors' research work concentrated on the required strength levels for obtaining design strength and the appropriate ductility for welded joints. For mismatched weld joints, it was found that the strength of the joints was strongly influenced by geometrical factors, i.e. the size effect caused by the plastic constraint could be clearly observed.

At the beginning of the 1970s the fracture strength of mismatched weld joints had been investigated by the authors' group ${ }^{7-8}$. Again the plastic constraint effect was found to be a main controlling factor ${ }^{9}$. Then, about ten years ago, active investigations of mismatched weld joints began on an international scale, and recently a large international conference ${ }^{10}$ was held to report on mismatching problems.

The plastic constraint in the lower strength region adjacent to hard materials plays an important role in the static and fracture strength behaviors.

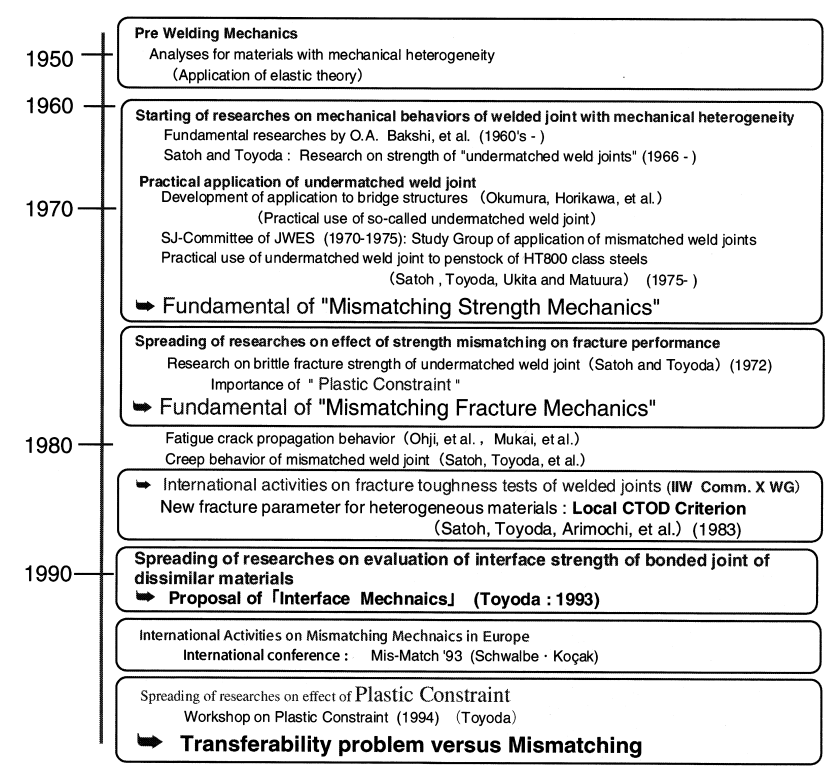

Figure 3: Trend of achievements of mechanical researchers for mismatched materials

Slika 3: Razvoj dosežkov raziskovalcev na področju lomno mehanskih raziskav trdnostno neenakih materialov

\section{TENSILE STRENGTH OF AN UNDER-MATCHED WELD JOINT DURING STATIC AND DYNAMIC LOADING}

The devastating destruction caused by the recent Hanshin and Northridge earthquakes has brought to our attention the necessity for assessing fracture behavior under dynamic loading. In order to confirm the combined effect of both mismatching and dynamic loading, tensile tests of undermatched weld joints under different loading rates have been carried out. Under-matched joints were made for a HT50 plate steel, for an insert metal between HT80 plate steels and for the base metal. The under-matched joints were bonded by diffusion. By using this diffusion-bonding technique, typical model joints with an under-matched layer can be obtained. The relative thickness $\mathrm{X}=\mathrm{H} / \mathrm{D}$, which is defined as the ratio of the thickness of the under-matched interlayer $\mathrm{H}$ and the diameter of the specimen $\mathrm{D}$, are varied as $\mathrm{X}=0.15,0.3$, and 1.0 (Figure 4).

Dynamic tensile tests and numerical simulations have been performed for the above under-matched weld joint by using various strain rates and test temperatures. The effects of the relative thickness of the under-matched joints on yield stress and tensile strength are shown in Figure 5. The effect of relative thickness on the tensile strength of under-matched joints is the same as in our previous studies, even under dynamic loading. The strength of the welded joint approaches that of the base metal when the thickness of the soft interlayer becomes smaller, and this tendency does not depend on strain rate.

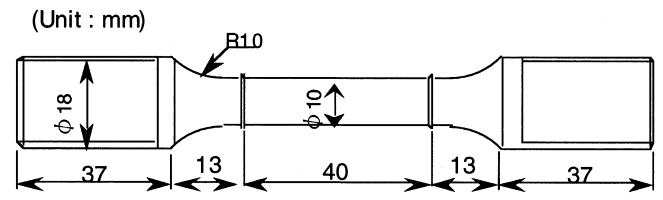

(a) Homogeneous specimen

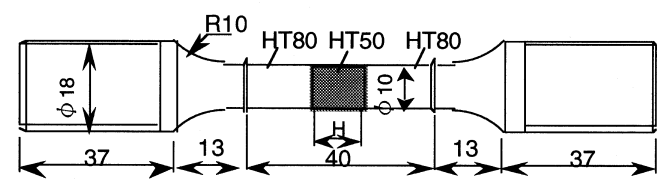

(b) Undermatched joint

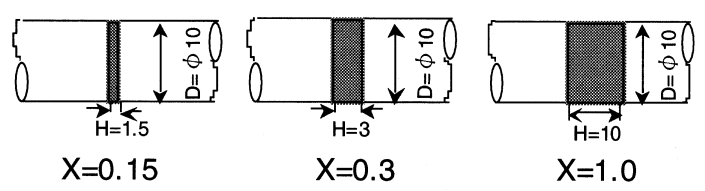

Relative thickness $\mathrm{X}=\mathrm{H} / \mathrm{D}$

(c) Relative thickness change of undermatched joint

Figure 4: Configuration of round-bar tension specimen and definition of relative thickness

Slika 4: Oblika okroglega nateznega preizkušanca in definicija relativne debeline 


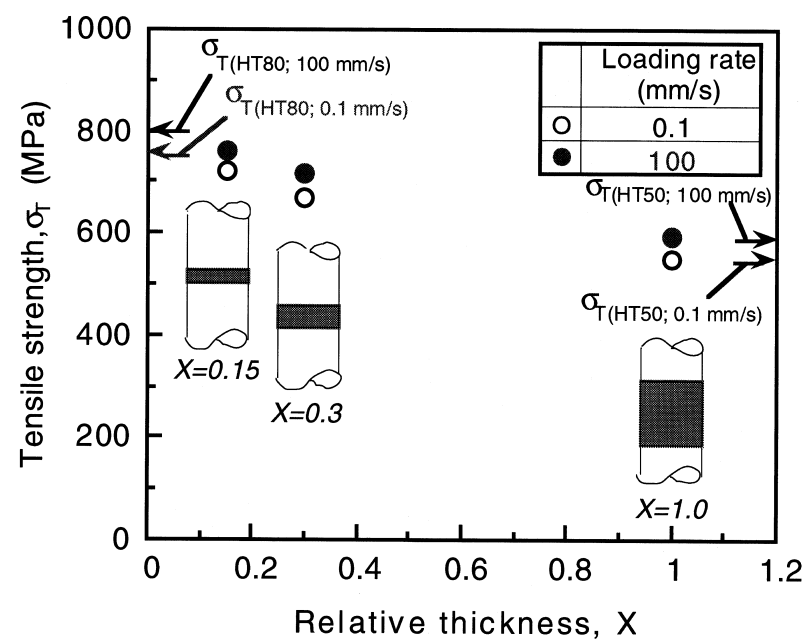

Figure 5: Relationship between tensile strength and relative thickness in undermatched joints

Slika 5: Odvisnost med natezno trdnostjo in relativno debelino pri zvarnih spojih z manjšo trdnostjo vara

On the other hand, the plastic constraint must affect the fracture behavior of welded joints with undermatched layers. The effects of temperature and strain rate on the crystallinity of under-matched joints are shown in Figure 6. The ductile-to-brittle transition curve shifts to high temperatures when the relative thickness becomes smaller, and it does not depend on strain rate. This phenomenon is considered to be the reason why the plastic constraint in the center of the cross-section in the soft interlayer affects the fracture initiation. Furthermore, the transition curve under dynamic loading is located at the lower temperature side compared to the curve for static loading. This phenomenon seems to contradict conventional results. The shift to lower temperatures under dynamic loading compared to static

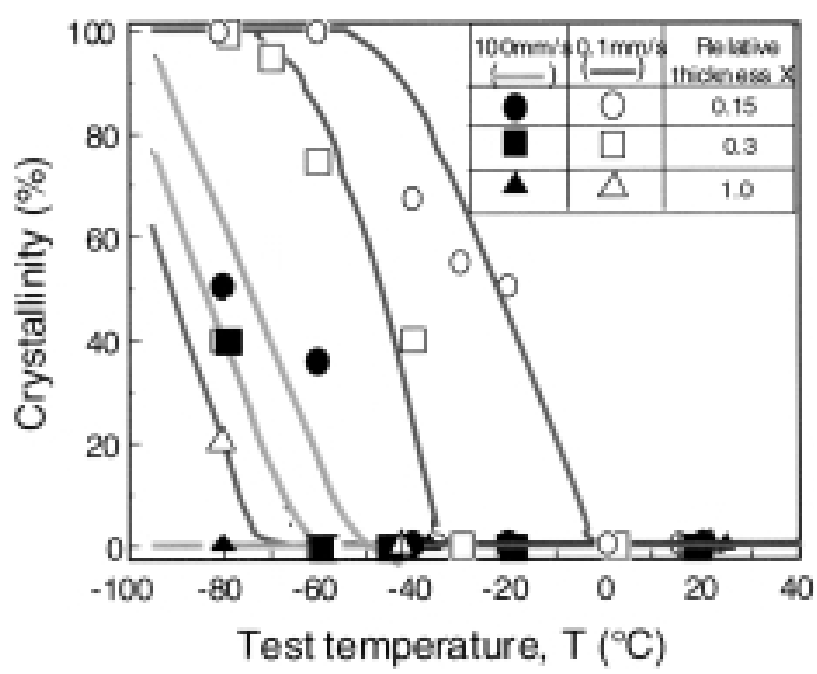

Figure 6: Comparison of ductile-to-brittle transition behavior in undermatched joints

Slika 6: Primerjava področij prehoda iz žilavega v krhki lom pri zvarnih spojih z manjšo trdnostjo vara loading can be explained by the curves in Figure 7. The ductile-to-brittle transition curve under dynamic loading receives not only the shift to higher temperatures due to the increase of strain rates but also a shift to lower temperatures due to temperature increases resulting from plastic deformation.

In order to evaluate the fracture performance of welded joints with a strength mismatch, the appropriate criteria for the change of plastic constraints have to be clarified.

\section{A TRANSFERABLE CONCEPT FOR DUCTILE CRACK INITIATION}

It is well known that ductile crack initiation is mainly controlled by the critical strain, which is strongly influenced by the stress triaxiality at the fracture initiation point. The criteria for ductile crack initiation are widely used in situations where the equivalent plastic strain reaches the critical value as a function of stress triaxiality ${ }^{12,13}$. The applicability of the above concept has been confirmed so far by using notched specimens for various structural steels. In the present experiments, the applicability of the two-parameter (equivalent strain versus stress triaxiality) criterion has been clarified in the case of ductile crack initiation for welded joints with a strength mismatch as well as for cracking under dynamic loading.

Figure 8 shows the relationship between the equivalent plastic strain and the stress triaxiality in fully ductile fractured specimens under static and dynamic loading for both homogeneous and under-matched weld joints. Also shown are the results for homogeneous round bars with circumferential notches. Both the equivalent strain and stress states were calculated by using finite-element-model (FEM) analyses based on the

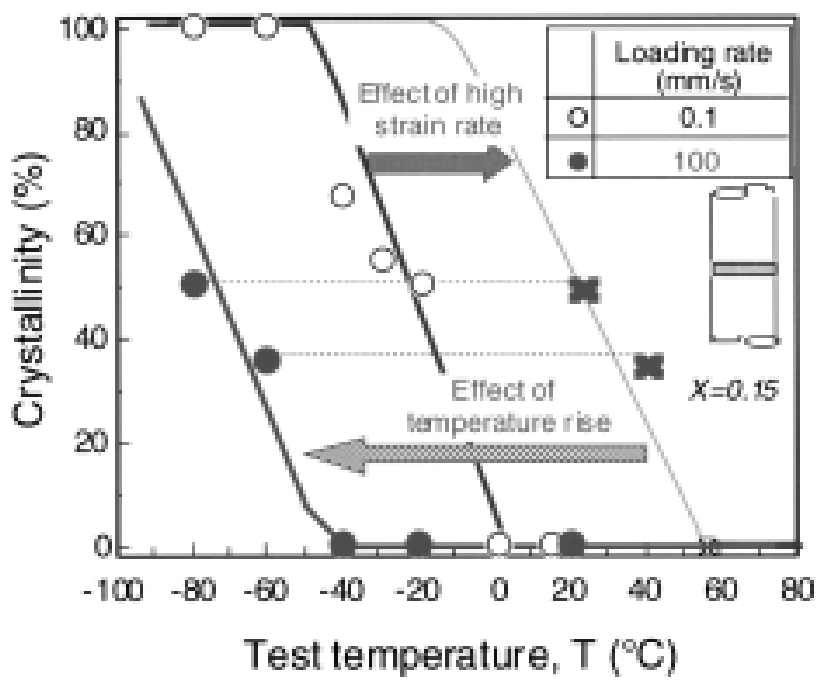

Figure 7: Explanation of shift of ductile-to-brittle transition temperature in undermatched joint

Slika 7: Razlaga premaknitve prehodne temperature iz žilavega v krhki lom pri zvarnih spojih z manjšo trdnostjo vara 


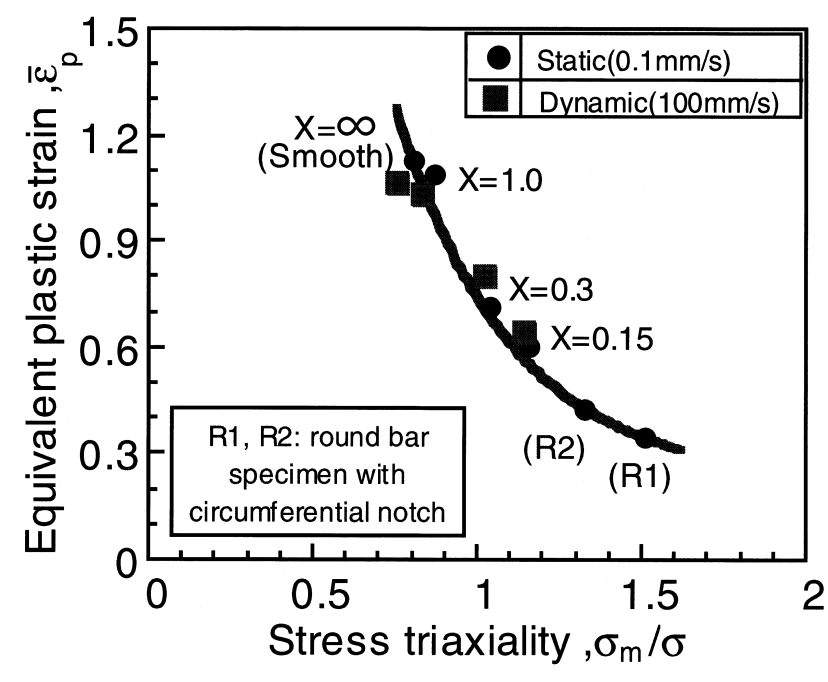

Figure 8: Relationship between equivalent plastic strain and stress triaxiality at ductile crack initiation in HT 50 steel for various loading conditions and specimen geometry

Slika 8: Odvisnost med ekvivalentno plastično deformacijo in triosnim napetostnim stanjem na konici razpoke pri iniciaciji žilavega loma v jeklu HT 50 za različne obremenitve in geometrijo preizkušanca

thermal elastic-plastic analysis under static and dynamic loading conditions. It should be noted that in order to analyze the stress-strain behavior of under-matched welded joints under dynamic loading the numerical simulations of the coupling phenomena of temperature and stress-strain fields and the use of the precise stress-strain relation at a certain temperature and strain rate are indispensable.

As shown in Figure 8, the two-parameter criterion becomes a candidate for a transferable fracture criterion even under different plastic constraint conditions due to the existence of strength mismatching and under dynamic loading conditions. The critical condition for ductile crack initiation can be evaluated based on the two-parameter criterion by using the hysteresis of equivalent plastic strain versus stress triaxiality.

\section{A TRANSFERABLE CONCEPT FOR BRITTLE FRACTURE WITH CONSIDERATION OF THE PLASTIC CONSTRAINT EFFECT}

\subsection{Effect of strength mismatching on critical CTOD}

It is well known that the critical fracture-toughness values: $\mathrm{K}_{\mathrm{c}}, \mathrm{J}_{\mathrm{c}}$ and $\delta_{\mathrm{c}}$ are influenced by the type and size of the testing specimens ${ }^{14}$. According to previous fracture-toughness tests using common CTOD specimens, the critical CTOD depended a lot on the notch depth $(\alpha / \mathrm{W})$. A shallow-notch specimen provides a significantly larger critical CTOD value than a deep-notch specimen. Moreover, it is well known that the tension specimens give higher critical CTOD values than the deep-notch bend specimen. The reason for the geometrical effect observed in the conventional fracture parameters such as critical CTOD or J-integral is the change of the plastic constraint effect in the vicinity of crack tips.

The same behavior can be seen in the fracture behavior of HAZ notched specimens of welded joints with considerable strength mismatching, i.e. matching of weld metal to base metal. Figure 9 displays a typical result of the observation that the critical CTOD is dependent on mismatching. The critical CTOD increases if under-matched weld metal exists in the vicinity of crack tips (Figure 9b), and it decreases in the opposite case (Figure 9a). It is apparent that the common fracture criterion based on CTOD or $\mathrm{J}$ is not transferable to cases under various plastic constraint conditions. Therefore, the question arises which values should be adopted for evaluating the fracture performance of practical structures.

\subsection{Transferable concept for brittle fracture: two- parameter criterion and local approach}

As mentioned above, in the one-parameter approach based on common fracture mechanics, there is a limitation in the applicability of toughness data for the assessment of the fracture integrity of practical welded structures.

Several years ago, two progressive methods were proposed to address the specimen geometry effect on the fracture resistance. In the J-T and J-Q theories ${ }^{15-19}$ the $\mathrm{T}$ stress and $\mathrm{Q}$ parameters are introduced to quantify the difference between the full-field solution for the near-crack-tip stress distribution and the $\mathrm{K}$ - and HRR-controlled 20,21 stress fields. The procedure reportedly explains the geometrical dependence of the $\mathrm{J}_{\mathrm{c}}$ values by means of the $\mathrm{T}$ stress and $\mathrm{Q}$ parameters under the given conditions for the fracture criterion and the corresponding material parameters. Another method is the local approach ${ }^{22,23}$, in which the Weibull stress $\left(\sigma_{\mathrm{W}}\right)$ is defined as the new crack driving force. The local approach is based on the advanced weakest link model. The Weibull stress $\left(\sigma_{\mathrm{W}}\right)$ at brittle fracture initiation obeys the Weibull distribution with two parameters that are independent of the geometry of the test specimens. The above flow for the generalization of fracturemechanics approach from one-parameter to local approach is shown in Figure $\mathbf{1 0 .}$

The local approach employs the Weibull stress $\left(\sigma_{\mathrm{W}}\right)$ as a crack driving force, which is defined by the integration of an effective stress over the fracture process zone. The Weibull stress can be evaluated by ${ }^{24}$ :

$$
\sigma_{W}=\left[\frac{1}{V_{0}} \int_{V_{f}}\left[\sigma_{e f f}\right]^{m} d V_{f}\right]^{\frac{1}{m}}
$$

where $\mathrm{m}$ is the Weibull shape parameter, and $\mathrm{V}_{0}$ and $\mathrm{V}_{\mathrm{f}}$ are a reference volume defined in the local approach 

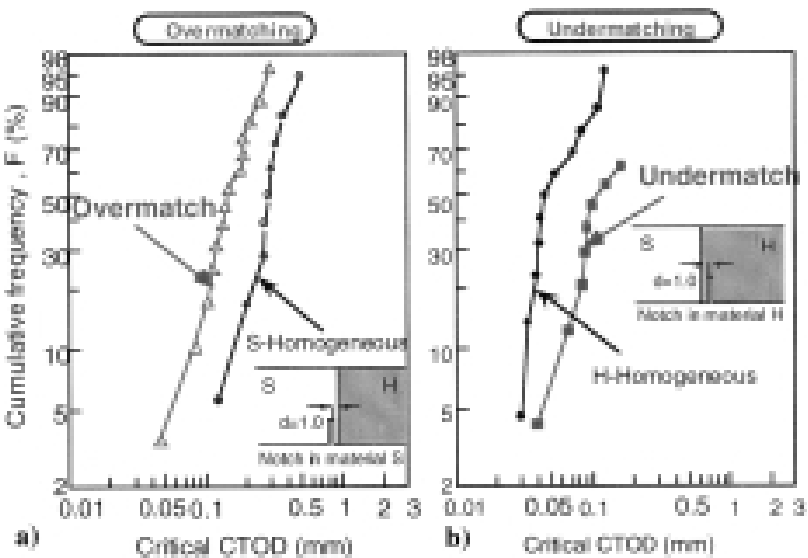

Figure 9: Effect of strength mismatching in the vicinity of notch tip on critical CTOD, a) Overmatching, b) Undermatching

Slika 9: Vpliv trdnostne neenakosti na konici razpoke na kriticno vrednost CTOD, a) Trdnostno višji var, b) Trdnostno nižji var and the volume of the fracture process zone, respectively. The effective stress, which controls the brittle fracture initiation, can be written as 24 :

$\sigma_{e f f}=\left[\frac{1}{2 p} \int_{0}^{\pi} \int_{0}^{\pi}\left[\sigma_{n}^{2}+\frac{4}{(2-v)^{2}} \tau^{2}\right]^{\frac{m}{2}} \sin \theta d \theta d \varphi\right]^{\frac{1}{m}}$

where $\sigma_{\mathrm{n}}$ and $\tau$ are the normal stress and the in-plane maximum shear stress for the microcrack, respectively, and the angles $\theta$ and $\varphi$ define the orientation of the microcrack relative to the principal stress axes. The co-planar energy release rate is employed as a fracture criterion under the multi-axial stress state. A random incidence of micro-cracks in the fracture process zone is assumed.

In the local approach, both the peak stress level in the vicinity of the crack tips and the spreading area of the higher stress regions are considered in the Weibull stress.

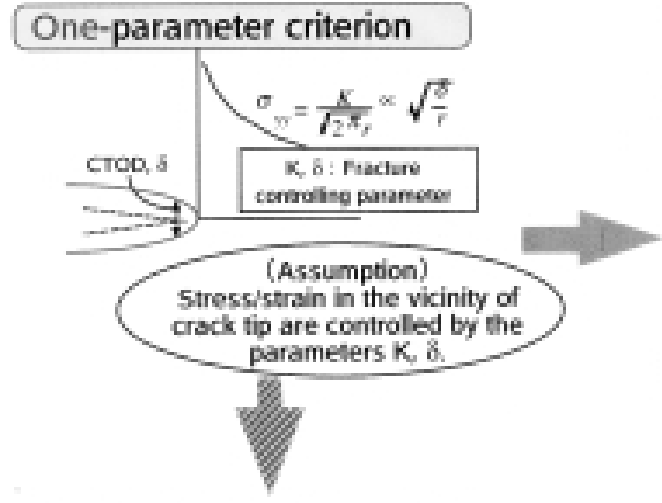

Two-parameter criterion
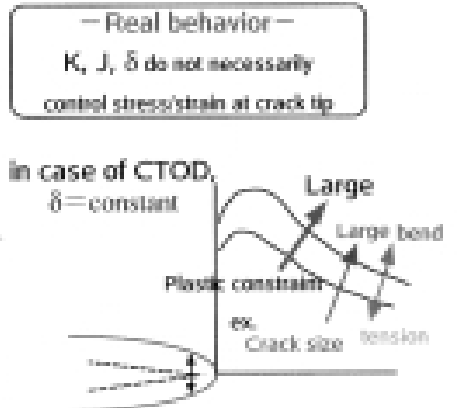

Sreas in the vicinky of orack $1 p$ is considerably dependart on the decres of plusise consitiant under a corstant fiactire mochenics parameter
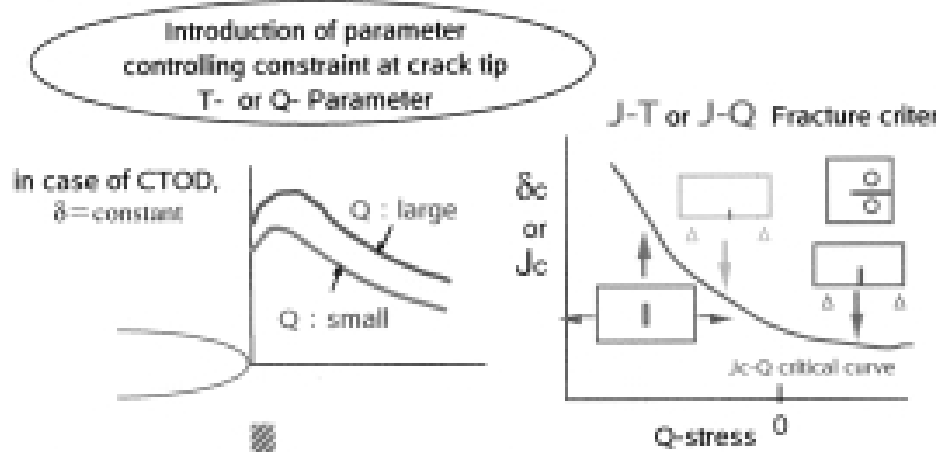

For generalizing

\section{Local Approach}

Criterion with considering stress distribution in the vicinity of crack tip ; Fracture parameter $=$ Weibull stress $\alpha_{w}$

$$
\sigma_{V}=\left[\frac{1}{V_{0}} \int_{V_{\operatorname{maxx}}}(\sigma)_{\theta j}^{m i} d V\right]^{1 / m}
$$

Figure 10: Flow for generalization of fracture-mechanics approach from one-parameter to local approach Slika 10: Potek posplošitve lomno mehanskega načina od enoparametrskega do lokalnega načina 


\section{TRANSFERABILITY OF THE LOCAL APPROACH}

The possibility of the local approach as a transferable criterion for brittle fracture assessment was pointed out in the preceding section. In the present section the applicability of the local approach in the evaluation of the fracture performance of welded joints with strength mismatching, even under dynamic loading, is discussed. Also, examples of engineering applications for the transferable concept are given.

\subsection{Evaluation of the fracture performance of welded joints with mismatching weld metal based on the local approach}

The validity of the local approach was investigated by an analysis of the transferability of 3-point bend CTOD results to a fracture performance evaluation of wide plates with strength mismatching. For comparison, an analysis based on the conventional CTOD concept was also conducted ${ }^{25}$.

Three types of joints, under-matched, matched and over-matched welded joints were fabricated by a mechanized gas-metal arc-welding (GMAW) process. For the base steel we used a high-strength pipeline steel (X80) of Grade 550 with a thickness $\mathrm{t}=25 \mathrm{~mm}$. The degree of strength mismatching, in terms of the yield strength ratio $\mathrm{s}_{\mathrm{Y}} \mathrm{W} / \mathrm{s}_{\mathrm{Y}}{ }^{\mathrm{B}}$ between the base and weld metals for the under-matched and over-matched joints, was about $10 \%$. Wide-plate specimens and 3-point bend specimens with a notch in the weld metal were extracted from these welded joints. The notch was located at the center of the weld metal at the root side of the welds. The wide plate was $300 \mathrm{~mm}$ long and $400 \mathrm{~mm}$ wide in the test section, and had a surface notch of $2 \mathrm{a}=100 \mathrm{~mm}$

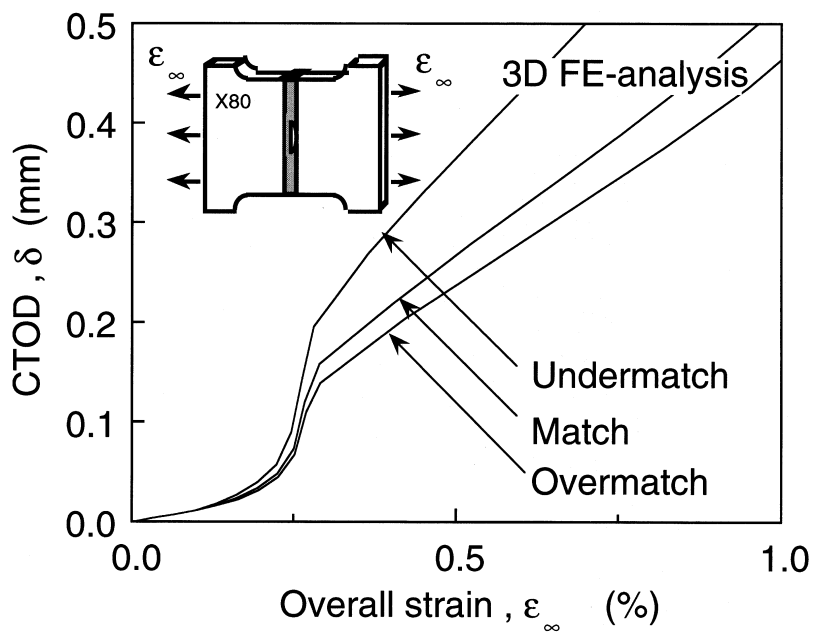

Figure 11: Influence of strength mismatching between base and weld metals on overall strain $e_{\infty}$ versus CTOD- $\delta$ relation for wide plates obtained by 3D FEM analysis

Slika 11: Vpliv trdnostne neenakosti med osnovnim materialom in varom na razmerje med celotno deformacijo $e_{\infty}$ in vrednostjo CTOD- $\delta$ za široke preizkušance, dobljeno z numerično analizo 3D MKE

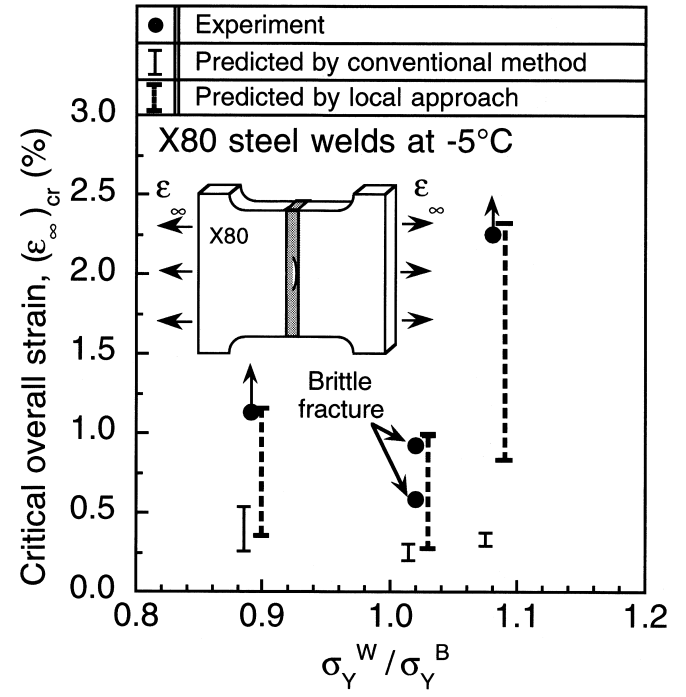

Figure 12: Comparison between critical overall strain $\left(\mathrm{e}_{\infty}\right)_{\mathrm{cr}}$ of wide plates predicted by both the conventional CTOD concept and the local approach, and that measured in the experiment

Slika 12: Primerjava med izračunano vrednostjo kritične celotne deformacije $\left(\mathrm{e}_{\infty}\right)_{\text {cr }} \mathrm{s}$ klasičnim konceptom CTOD in lokalnim načinom ter izmerjeno - eksperimentalno vrednostjo kritične celotne deformacije $\left(\mathrm{e}_{\infty}\right)_{\mathrm{cr}} \mathrm{V}$ širokih preizkušancih

(length) and $b=6 \mathrm{~mm}$ (depth). A fatigue pre-crack was introduced at the tip of the machined notch. The main objective of this study was the transferability of the 3-point CTOD results to the fracture-performance evaluation of the wide plates. In order to address this subject, FEM analysis was performed for the 3-point bend specimens and wide plates with a surface crack.

The relationship between the CTOD $-\delta$ and the overall strain $\left(\varepsilon_{\infty}\right)$ for the wide plates obtained from the 3D FEM analysis is shown in Figure 11. The strengthmismatch effect is observed from the $\delta-\varepsilon_{\infty}$ relation. According to the conventional CTOD design-curve approach, the critical overall strain $\left(\varepsilon_{\infty}\right)_{\text {cr }}$ of the wide plate is directly related to the critical CTOD value measured in the 3-point bend test. The estimated range of the critical overall strain $\left(\varepsilon_{\infty}\right)_{\text {cr }}$ for the wide plates is shown in Figure 12 together with the experimental results. It is found that the conventional CTOD concept yields very conservative estimates of the deformability of the wide plates.

The critical overall strains $\left(\varepsilon_{\infty}\right)_{\text {cr }}$ of the wide plates predicted by the local approach is shown in Figure 12. The local approach gives more reasonable predictions of $\left(\varepsilon_{\infty}\right)_{\text {cr }}$ for wide plates compared to the conventional CTOD.

\subsection{The Applicability of the Weibull-stress approach for fracture under dynamic loading}

It is known that dynamic fracture toughness obtained in tests under high-speed loading deteriorates compared to the ordinal static fracture toughness ${ }^{26}$. Typical 

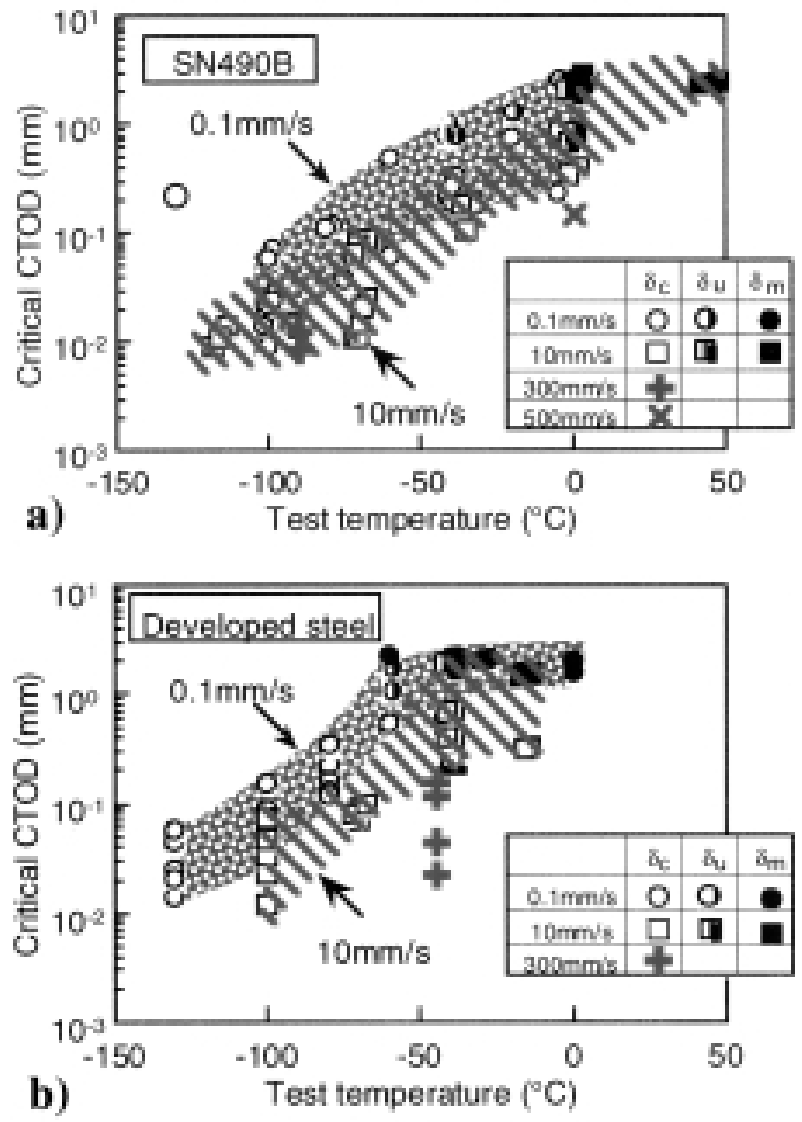

Figure 13: Effect of loading rate on critical CTOD for CT-type specimens, a) Steel A (HT 50), b) Weld Metal (HT 50)

Slika 13: Vpliv hitrosti obremenjevanja na kritično vrednost CTOD pri CT-preizkušancih, a) Jeklo A (HT 50), b) Var (HT 50)

examples of the effect of strain rates on critical CTOD values obtained by CT-type CTOD tests under static and dynamic loading are shown in Figure 13. The deterioration is mainly due to the increase in strength of steels under dynamic loading which causes the increase in stress levels in the vicinity of crack tips. The applicability of the local approach can be presumed because dynamic fracture toughness is controlled by the stress conditions under dynamic loading.

For the determination of the critical Weibull stress, the accurate stress-strain distributions of the adopted specimens should be evaluated under both static and dynamic loading. By using the same procedure mentioned above, FEM analyses were conducted for the results shown in Figure 13. Figure 14 shows the median of $\sigma_{\mathrm{W}, \mathrm{cr}}$ as a function of the strain-rate temperature parameter R value given in Figure 14, obtained from the calculated results of the cumulative distribution of $\sigma_{\mathrm{W}, \text { cr }}$ at the onset of brittle fracture. It can be seen that the median of $\sigma_{\mathrm{W}, \text { cr }}$ does not depend on the parameter $\mathrm{R}$. Consequently, the brittle fracture resistance evaluated by the Weibull stress is a material property independent of the loading rate under the test conditions.

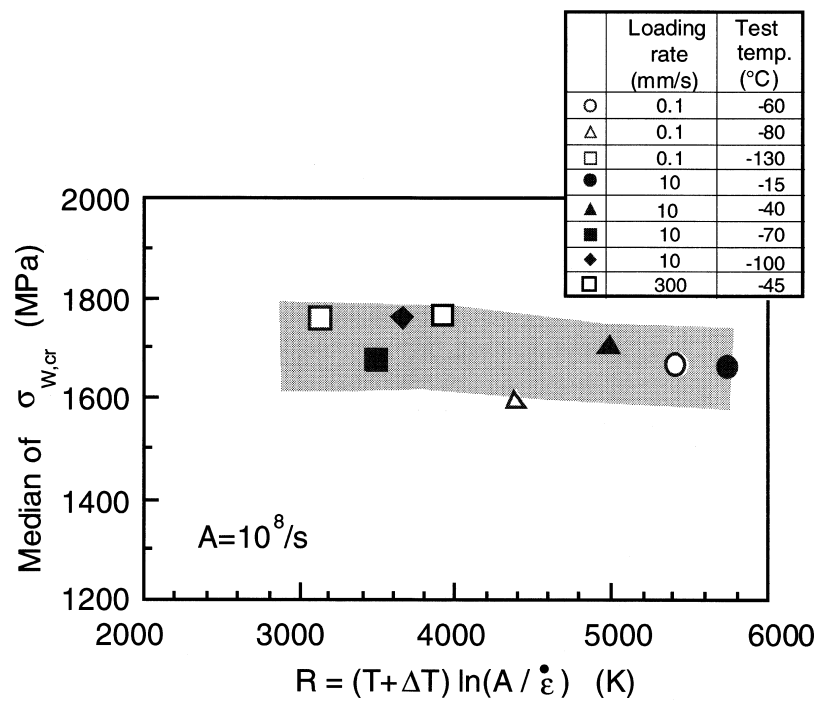

Figure 14: Median of critical Weibull stress in different test conditions

Slika 14: Srednja vrednost kritične Weibullijeve napetosti pri različnih pogojih preizkušanja

The effects of the dynamic loading on the critical CTOD is predicted on the basis of the Weibull-stress fracture criterion, with the assumption that the critical Weibull-stress $\left(\sigma_{\mathrm{W}, \mathrm{cr}}\right)$ at brittle fracture initiation is independent of the loading rate and the test temperature as far as the brittle fracture dominates the failure mode of the material.

The predicted distributions of the critical CTOD and the experimental results are compared in Figure 15. As a reference, the CTOD distribution (symbol O) in the static condition is also presented. It can be seen that the local approach is a transferable concept for the dynamic fracture toughness.

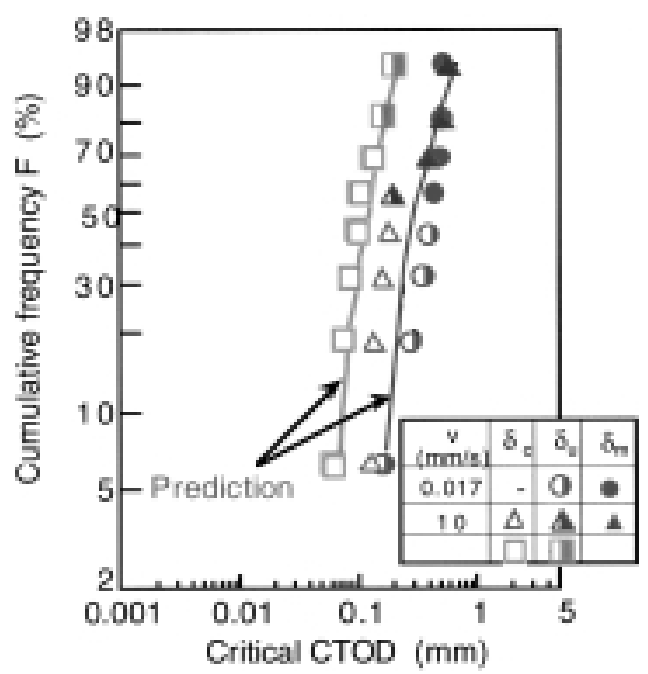

Figure 15: Cumulative distribution of critical CTOD under dynamic loading predicted by the local approach

Slika 15: Napoved kumulativne porazdelitve kritične vrednosti CTOD pri dinamičnem obremenjevanju $\mathrm{z}$ uporabo lokalnega načina 


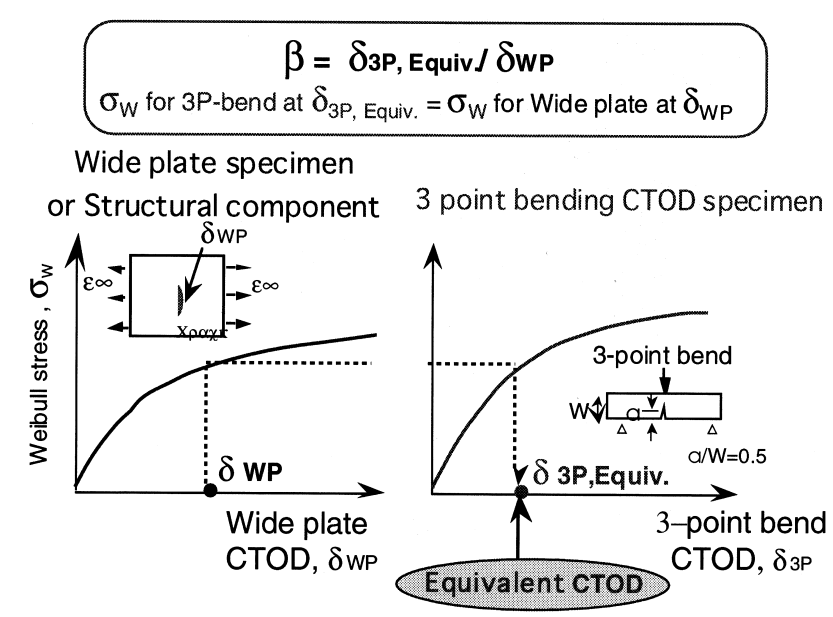

Figure 16: Fundamental idea of equivalent critical CTOD concept Slika 16: Temeljna ideja kritičnega ekvivalentnega koncepta CTOD

\subsection{The Equivalent CTOD concept}

Based on a transferable concept such as the local approach, the effect in the difference of plastic conditions of practical structural members and fracturetoughness test specimens with a deep-notch can be evaluated by using the equivalent CTOD concept 27,28 . The key idea of the equivalent CTOD concept is illustrated in Figure 16. The equivalent CTOD is defined by the CTOD $\delta_{3 \text { P,Equiv }}$ of the fracture-toughness specimen (a standard 3-point bend specimen with a deep notch is considered in this paper), where the toughness specimen presents a compatible Weibull stress with the structural component at a given CTOD level $\delta_{\mathrm{WP}}$ (CTOD in a wide plate or a structural member to be evaluated). In order to quantify the difference between $\delta_{3 P \text {,Equiv }}$ and $\delta_{\mathrm{WP}}$ we introduced the CTOD ratio:

$$
\beta=\delta_{3 \mathrm{P}, \text { Equiv }} / \delta_{\mathrm{WP}}
$$

With the $\beta$ value the transferable evaluation can be conducted based on the ordinal toughness data obtained with CTOD specimens.

The Japan Welding Engineering Society recently published a new engineering assessment procedure for steel structures under large, cyclic, and dynamic loading conditions such as seismic loading as per WES TR 2808. In this recommendation, the equivalent critical CTOD concept was adopted, and the $\beta$ value was given as shown in Figure 17.

\section{SUMMARY}

Metallurgical mismatching and geometrical discontinuity causes considerable plastic constraints, which play an important role in the fracture-initiation behavior. In the present paper the importance of the evaluation of the degree of plastic constraints in the

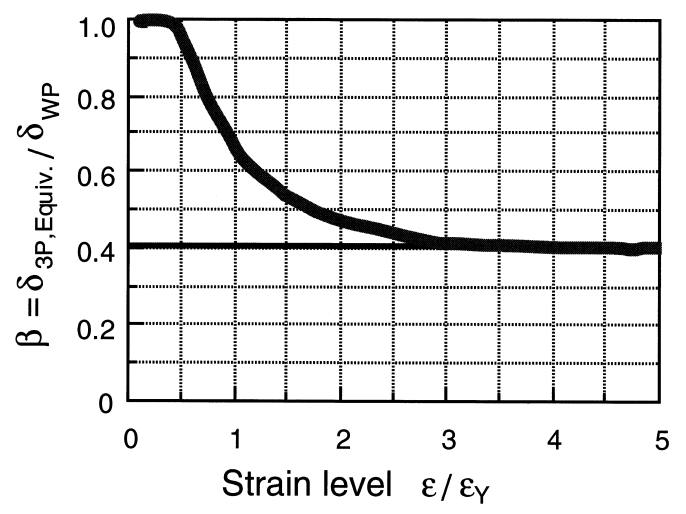

Figure 17: Distribution of $\beta$ value based on equivalent CTOD concept, adopted in WES TR 2808

Slika 17: Porazdelitev $\beta$-vrednosti na podlagi ekvivalentnega koncepta CTOD, uporabne v standardu WES TR 2808

vicinity of a crack was assessed in terms of a review of the fracture tests of welded joints.

The transferability of the common fracture mechanics parameters for both ductile crack and brittle fracture initiations was discussed in the context of recent activities regarding the fracture criterion such as the two-parameter concept and the local approach. The discussion of typical examples of the fracture behavior, e.g. mismatching effects on fracture toughness of a welded joint, confirmed that numerical simulations based on the transferable fracture concept are effective in practice.

\section{ACKNOWLEDGMENT}

The Japan Society for the Promotion of Science is thanked for providing financial support for this research program.

\section{REFERENCES}

${ }^{1}$ Toyoda, M.: "Interface Mechanics", Riko-gaku-sha, (1993) (in Japanese).

${ }^{2}$ Satoh, K., Doi, T. and Toyoda, M.: Size Effect on Static Tensile Properties of Welded Joints Including Soft Interlayer, Jl. of Japan Welding Society, 37(1967), 1214 (in Japanese).

${ }^{3}$ Satoh, K. and Toyoda, M.: Static Tensile Properties of Welded Joints Including Soft Interlayer, Trans. Japan Welding Society, 1(1970), 7 (in Japanese).

${ }^{4}$ Satoh, K., Toyoda, M. and Fujii, E.: Tensile Behaviors and Strength of Soft Welded Joints, J1. Soc. Naval Archit. Japan, 132(1972), 381 (in Japanese).

${ }^{5}$ Satoh, K. and Toyoda, M.: Joint Strength of Heavy Pates with Lower Strength Weld Metal, Welding Journal, 54(1975), 311s.

${ }^{6}$ Satoh, K., Toyoda, M., Ukita, K. and Matsuura, T.: Undermatching Electrode Applied to HT80 Heavy Plate for Penstock, Welding Journal, 58(1979), 25s.

${ }^{7}$ Satoh, K., Toyoda, M., and Arimochi, K.: Effect of Mechanical Heterogeneity on Brittle Fracture Behaviors, Jl. Soc. Naval Archit. Japan, 134(1973), 395 (in Japanese) . 
${ }^{8}$ Satoh, K., Toyoda, M., and Sakano, K.: Effect of Plastic Constraint on Brittle Fracture Initiation of Soft Welded Joints, J1. Soc. Naval Archit. Japan, 132(1972), 371 (in Japanese).

${ }^{9}$ Toyoda, M.: Constraint Effect - How to Link Between Fracture Toughness Evaluation and Structural Integrity Assessment -, Proc. of $14^{\text {th }}$ Int. Conf. on OMAE, Vol. III-A, (1995), 55-63, and Journal of Offshore Mechanics and Arctic Engineering, 119(1997), 125-133.

${ }^{10}$ Schwalbe, K.-H. and Koçak, M.: Mis-match '93 and '96, Luneberg.

${ }^{11}$ Toyoda, M., Mochizuki, M., An, G. B. and Ohmura, T.: Characteristics of Strength and Fracture in Undermatched Weld Joints by Dynamic Loading, IIW Doc. X-1459-00, and IIW Doc. SC X-F-090-00 (2000).

${ }^{12}$ McClintock, F. A.: A Criterion for Ductile Fracture by the Growth of Holes, Trans. ASME, J. Appl. Mech., 90 (1968), 363-371.

${ }^{13}$ Thomason, P. F.: A Theory for Ductile Fracture by Internal Necking of Cavities, J. Inst. Met., 96 (1968), 360-365.

${ }^{14}$ Minami, F., Ruggieri, C., Toyoda, M., Arimochi, K., Suzuki, S. and Bessyo, K.: Significance of Shallow Notch CTOD Test in Fracture Performance Evaluation of Welded Joint, Proc. $12^{\text {th }}$ Int. Conf. OMAE, Glasgow, 3B (1993), 761-768.

${ }^{15}$ Larsson, S. G. and Carlsson, A. J.: Influence of Non-Singular Stress Terms and Specimen Geometry on Small-Scale Yielding at Crack Tips in Elastic-Plastic Materials, J. Mech. Phys. Solids, 21 (1973), 263-277.

${ }^{16}$ Betegón, C. and Hancock, J. W.: Two-Parameter Characterization of Elastic-Plastic Crack-Tip Fields, J. Applied Mechanics, 58 (1991), 104-110.

${ }^{17}$ Wang, Y.-Y.: Two-Parameter Characterization of Elastic-Plastic Crack-Tip Fields and Applications to Cleavage Fracture, Ph. D. Thesis, Department of Mechanical Engineering, Massachusetts Institute of Technology, May, (1991).

${ }^{18}$ O'Dowd, N.P. and Shih, C.F.: Family of Crack-Tip Fields Characterization by a Triaxiality Parameter - I. Structure of Fields, J. Mech. Phys. Solids, 39(1991), 989-1015.
${ }^{19}$ O’Dowd, N.P. and Shih, C.F.: Family of Crack-Tip Fields Characterization by a Triaxiality Parameter - II. Fracture Applications, J. Mech. Phys. Solids, 40 (1992), 939-963.

${ }^{20}$ Hutchinson, J.W.: Singular Behavior at the End of a Tensile Crack in a Hardening Material, J. Mech. Phys. Solids, 16 (1968), 13-31.

${ }^{21}$ Rice, J.R. and Rosengren, G.F.: Plane Strain Deformation Near a Crack Tip in a Power Law Hardening Material, J. Mech. Phys. Solids, 16 (1968), 1-12.

${ }^{22}$ Beremin, F. M.: A Local Criterion for Cleavage Fracture of a Nuclear Pressure Vessel Steel, Metallurgical Trans. A, 14A (1983), 2277-2287.

${ }^{23}$ Mudry, F.: A Local Approach to Cleavage Fracture, Nuclear Engineering Design, 105 (1987), 65-76.

${ }^{24}$ Toyoda, M., Minami, F., Ruggieri, C., Thaulow, C. and Hauge, M.: Fracture Property of HAZ-Notched Weld Joint with Mechanical Mis-Matching - Part 1. Analysis of Strength Mis-Matching of Welds on Fracture Initiation Resistance of HAZ-Notched Joint, Mis-Matching of Welds, ESIS Publication 17 (Edited by Schwalbe, K.-H. and Koçak, M.) (1994), 399-415.

${ }^{25}$ Minami, F., Ohata, M., Toyoda, M., et al.: Yield Strength Mis-Match Effect on Fracture Performance of Girth Welded Joints of Grade 550 Pipeline Steel, Pipeline Technology, 1(1996), 441-461

${ }^{26}$ Minami, F., Hashida, T., Toyoda, M., et al.: Dynamic Fracture Toughness Evaluation of Structural Steels Based on the Local Approach - Application of the Local Approach to Fracture Control Design - , J1. Soc. Naval Archit. Japan, 184(1998), 457-468 (in Japanese)

${ }^{27}$ Minami, F., Ohata, M., Toyoda, M. and Arimochi, K.: Determination of Required Fracture Toughness of Materials Considering Transferability to Fracture Performance Evaluation for Structural Components - Application of the Local Approach to Fracture Control Design - , Jl. Soc. Naval Archit. Japan, 182(1997), 647-657 (in Japanese)

${ }^{28}$ Minami, F., Katou, T., Nakamura, T., and Arimochi, K.: Equivalent CTOD Concept for Fracture Toughness Requirement of Materials for Steel Structures, OMAE99/MAT-2130 (1999) 